\title{
Property, Specified Knowledge and Competence in Higher Education
}

\author{
Lirika Kutrolli, PhD \\ European University of Tirana, The Civil Right Department \\ E-mail: Ikutrolli@yahoo.com
}

\section{Doi:10.5901/mjss.2014.v5n8p328}

\section{Abstract}

Reforms in Albania are developed at a positive side in many fields of the right. Radical reforms are developed in educational sector, in public sector also in the private one. Our society has shown interest in learning and the private section has been responded well in this. The success in the educational field has been analyzed only in one institution (The directory of the public relation in the council of ministry for a period of years) where the people present their complaints of any nature, that belong to different areas of the law. From the research work in this institution, reclaims in the educational field are minimal and compared to other fields and we see that the biggest problem are in the ownership right. These problems need solution and the solution demands capacity, competence, qualified people, lawyers, brave experts and we must search the bases of this qualification in the programs of law faculty in our universities. The research question that was lodged in this paper is: Do law students gain the right amount of knowledge for the land and property in the auditorium? Are they able to work in sectors that address issues about property and ownership? Interviews with students from the faculty of several universities of justice are used as an argument to prove that they specifically admit "we have not enough knowledge on issues as property and ownership". Review of programs in our law faculties will increase the knowledge and form more competent lawyers, guarantying the right to property as a fundamental right. In this point of view, in law faculties, the program of "Ownership Property" should have more space and treated as a separate subject. The solution of ownership matters is a current challenge.

Keywords: university, property, competence, lawyers, challenge.

\section{Introduction}

\subsection{The importance of this project}

I recall in front of academics a concerning problem by a part of Albanian society. Property matters have become now day issues and the solution demands coordination and undertaking of many actors together, one of these is the educational sector.

Appeal for resolving ownership issues comes from internationals (World Bank, European Courts of Human Right)

\subsection{Research question}

In what way does the curriculum and ownership property respond to current developments of the country for the whole amendments in ownership field, in the last five years?

How contributes educational sector in the growth of capacities? How much brave lawyers can produce our society and how can they choose the complex and problematic matter of ownership?

\subsection{Methodology}

Primary sources (the interpretation and the legal analyze, study claims in a government institution)

Secondary source (studies of World Bank, progress report, different organization, internet)

\subsection{Arguments}

Educational sector takes an important place impacting lore at society, in auditors, the place where we expect the growing and training of capacities. We should demand results after we have identified the problem that exists in higher educational curriculum and especially in content of ownership right. If we enrich this subject with specific thematic that 
responses well to actuality and are in coherence with the current developments and with expectations and training of brave lawyers, the capacities of property field will be higher.

Programs in law faculties are deficiencies in content and lore that should pass to students, about institutions, land laws and legal changes that take an important place in property relations, as a key factor in developments of the country. Following the interviews of law students in private sector as in public one, we conclude that the subject content is poor. To transfer lore in the field of ownership is a necessity and appeal comes from the internationals.

\section{Development}

In this project we present the positive progress related to the growth of students in higher educational. Progress is visible, but we have an important job to do. "Quality" is an element which is in competition with all private and public operators.

We will analyze the importance of a specific subject, for its role in current conditions of the country.

Ownership right is treated as a separate subject in some law faculties, and in others not. This way it diffuses the program to other subjects. It is very important to compose a curriculum with programs that has the appropriate content, so it can fulfill students demands about specific knowledge and current developments of the country. In our case the ownership right is a subject which should treated as a separate one, because of the importance and role that properties have, as a key factor in the progress of the country.

We will analyze the place that this subject has and must have in the curriculum. Curriculum is basic to lead the lore to society. A good curriculum will give opportunity to develop and grow the capacities, and then to increase reforms in country. The intention and the purpose of the project is to recall academics about a problem which needs contribution, and support of educational ministry in way to grow capacities through developing the programs for each subject, such as "ownership right' It is very important to compose curriculum with content, this way it can be adapted with students requirements and with country progress. In our case property is a subject which should be treated separated by other subjects because of its importance and evolution. Progress in the educational sector is obvious, because the higher educational system in Albania has it source since 1946 with the 2 year pedagogical institute Tirana. The first university in country is the university of Tirana, which is opened in 1957, based on good tradition created by institutes of that time in Tirana. The pedagogical institute, polytechnic economic, medicine, law and science institute. Until 90", the educational system was based on Russian model but after 90 " many basic changes transform radically the most important sectors in property matters, educational field etc. These reforms demand a new organization of educational system. Our society has no experience and has many difficulties to adapt and accept new reforms. We didn't have an Albanian model to follow, so this made the thinks more difficult to realize ${ }^{1}$. Albanians were hungry to learn, they still are eager and they always want more to fulfill their requirements in society and in market.

\section{Massive}

The first private university in the country was opened in $2003^{2}$ today this number is growing in huge dimension. In 2005 there were 17 people with high education in 100 citizens, today this number is 22 citizens with high education 100 people. We must take in consider that this percent is low, because the most of citizens with age 50 years and older are without high educational training ${ }^{3}$. Refer to studies of $\mathrm{BB}$, Albania has the low percentage of people with middle educational (48.74 \%) referred $62 \%$ that has Balkan countries this number is growing this years. In these years (referred 2005-2009) is growing from 22 to $37 \%$ in higher educational. Despite the growth. Albania yet has the lowest grade compared to other place in region ${ }^{4}$. Changes of system in 1880 bring on massive emigration which include also the high educational system . Another study in 2008 emphases that after 1990 almost half of pedagogues and students in Albanian universities, leave the country, for a better life abroad. There are many assumptions today that the situation is worse in high educational on immediately decrease of this system compared with communist regime, where education was part of "elite people". In recent years, with increase of number of universities is growing also the number of private universities and the employment of many pedagogues in our institutes.

\footnotetext{
${ }^{1}$ Education Ministry, Instat, work and comments: open data Albania

2 Education Ministry, Instat work and comments: open data Albania

${ }^{3}$ Albanian News (2011)

${ }^{4}$ Albania: New Agenda of Economic Progress. work of World Bank, November 2010, page 15
} 


\section{Looking for quality}

The quality has been a challenge in the strategy of Ministry of high education (2012-2013-) But here is the question: How many progress have we done to realize this? We find results in different studies done by BB and Ministry of High Education and in foreign organizations. The expansion of high education and the increase of quality demands more pedagogues qualified in universities abroad. Based on ministry of education's data through excellence fund this year are being supported 70 candidates for PHD studies in universities abroad. On the other side, since July 2008150 people have been attracted in Albania, by program to return the brain called "brain gain" with a number of 82 pedagogues 5 . There are many actors that must be parallel and combined with each other. One of the actors that we must emphase is public subsidy ${ }^{6}$, and the financial support in private education sector.

The private or public concept should not exist in the perspective of freedom to choose. There are many elements that should exist like quality, curriculum, factors for scientific development, the possibility of creating teaching practices and capacity in teaching. These are the elements that should orientate people. The financial support is fundamental for students of private and public sector in field of scientific work.

We must see carefully the continuity of qualifications because the staff demands $m$ is the most important element that impacts lore at students and this way grows our society. Once upon a time there was no compatibility because there were no private sector. The increase of private sector today, brings as product the large number of people with high education, but this must be equal with quality. Initiative to value quality was a useful initiative, it should be present also in private educational sector. Universities create their profile through good products they bring, this way they give us brave students.

In Nation Strategy of High Education ( SKALA ) has defined : ".....the economic and social development in Albania demands the strength of science, technology, and innovation. These are the key factors of economy orientated at lore and are necessary to handle new challenges that are waiting for us in a new global world which is always more competitive. This strategy defines very well the vision and a lot of important objectives that are in harmony with objectives of nation strategy for progress and development, especially with those of high education strategy and with other sectional strategies. This is an important sign of government to put research, science, new technologies and innovation in the same place as other priorities of government."

It is recommended that pedagogues of subject in the second or third university studies circles must have the grade "doctor". To fulfill these objectives, all system will create, develop and transmit lore through teaching and scientific researches. ${ }^{7}$ In university system are demanding always more European standards. We need concrete impulse in scientific research and human potential to impact directly in economic and social development of the country. Shortage priorities for 2012-2013 for scientific research are8:

- Evaluation of legislation with new conditions after the reform of the scientific research system.

- Improving and harmonizing in progressive way Albanian legislation in the way that European council demands, for new conditions after the reform of the scientific research system.

- There are good and positive databases at the period of reforms that government has taken in education sector ${ }^{9}$. We will mention some of the priorities that guide increase of quality in high education, but problems in ownership right are still present because we don't have brave lawyers.

We are in that phase when Albania is expecting to receive EU candidate status and a condition imposed is to respect fundamental human rights. The right to property is a fundamental right protected by law. Solving problems of ownership is considered a priority and is very important among many participating actors, one of them is the education sector.

Education should contribute in the foundation and increasment of human capacity and resources. So, it is necessary to raise a very important question wethear lawyers have a good knowledge about the proprietorship branch or not, wethear they do qualify themselves systematically according to the different legislative changes during the time or not and of course wethear we do pay serious attention to this branch while we are drawing the faculty curriculum.

\footnotetext{
${ }^{5}$ Albania: New Agenda of Economic Progress. work of World Bank, November 2010, page 17, cited in Albanian Association Demographers, Tirana 2012, page 50

${ }^{6}$ The speech of Education ministry's minister in conference of 17 October 2011 for financial reform in high education which was not successful related to way how the private universities were managed. Cited in Albanian Association of Demographers Tirana 2012, page 58

7 Nation Strategy for High Education (SKALA)

${ }^{8}$ Based on agreement of stabilization and Association, shortage priorities 2012-2013

9 INSTAT-BB page 18 , page 36
} 
National World Bank has made a clear declaration on its annual reports about some problematic issues on proprietorship, on limitations in human capacity to solve problems, lack of programs for the provision of knowledge in this field, the necessity of preparing competent people etc.

The World National Bank's role and its contribution is a major influence on the epochal transformation of Albania. ${ }^{10}$

We can get a lot of information from various studies about the policies related to enhancing the quality orientation. In this study I would like to elaborate more in the curriculum and the place that specific subjects occupy in different programs. How much important is the place that e specific subject occupies in the whole faculty programs? Generally speaking, education encludes a whole range of developed reforms and their specific results, taking into consideration all the factors that influence education and that contribute into a final product. In the following passages we are going to deal with a research analyses about concluding educational reforms and the identification of a specific problem which needs to be taken into consideration whenever we speak about the curricula of Law Faculty.

There was conducted a state study in order to analyse the way that different complaints were positioned, the field of complaints and different problems regarding education in our country.

All the complaints were verified and recorded in the Public Relations Directorate of the Council of Ministers for a two years- period of time since 2009 until $2011 .{ }^{11}$ All the Albanian citizens have the have the legal right to submit their complaints to any problem that plagues and have not found a solution in institutions. All the verifications and analysis show that appeals to the field of education are lower compared to other sections. This result reflects the positive development of reforms which fulfill all the citizen's demands. However, what is striking is that property ownership issues takes the first place in the list of citizen's complaints.

This finding is one of the elements that can determine the results, the reforms in the sectors that we have taken for analysis. Unquestionably reforms are evident in every field of our country, but were they really successful? This chart gives us some answers, although this is relative, as the results of the reforms require a specialized job and we have to take into consideration many factors .

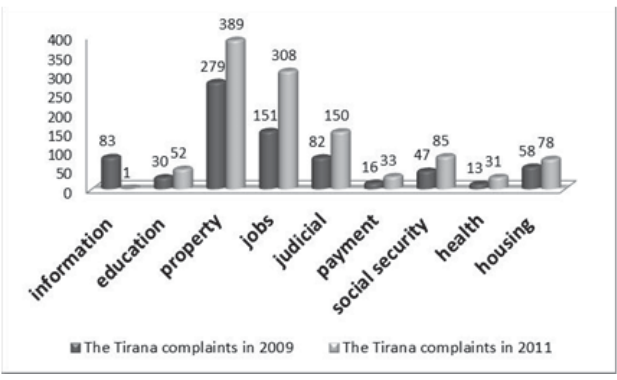

Figure 1. All the complaints made from the Albanian citizens recorded in the Prime Minister's Council are classified into various fields. They are all complaints made from 2009-2011.

To achieve the purpose and significance of this paper, we will first have to stop at the first column, the property, which is important to analyze it, as a problem that plagues every day more and more our society. The property issue is a very important problem in the Albanian's everyday complaints even in the International Court of Human Rights in our country. This court is an appeal to the Albanian government to solve problems with greater attention from the government to human capacities.

Now the issue has become a matter of everyday life. If we refer to the annual World National Bank's reports we can find a lot of interesting information about may problematic property issues that seek immediate solution. Moreover, we can notice that our country has a dominant limitation of human capacities and a lack of programs for the provision of knowledge in this field, the necessity of preparing competent people from the Law Faculty.

\footnotetext{
10 www.km.gov.al, October 5, 2012, Speech of Prime Minister Sali Berisha: "The World Bank's role and contribution, the main factors epochal transformation of Albania. Taking the floor, Prime Minister Berisha expressed his deepest gratitude and highest appreciation for the role, contribution and excellent contribution to BB to Albania and Albanians during the last 20 years. The Prime Minister stressed that thanks to this contribution, which has been substantiated in a number of important projects, Albanians today are grateful to BB for fundamental changes that have undergone such areas as infrastructure, education, health, energy, with the support of this institution is essential."
}

${ }^{11}$ Archival Fund of the Council of Ministers, the Archive of the Department of Public Relations, referring to 2009 and 2011 
Judicial reform is the main concern for the Ministry of Justice in the materialization of the Albanian Government policy to protect and establish human rights freedoms, restore the trust of citizens, enhance transparency and fight corruption.

The protection of property rights as one of the fundamental rights of the individual in a democratic state where law is the one who decides is also part os this reform. ${ }^{12}$

The strategy uses the findings and recommendations of the Memorandum of the Committee of Ministers of the Council of Europe, which requires comprehensive analysis of the problem of property rights, based not only on the current challenges that Albania is going through, but also in countries similar experiences other members of the Council of Europe in the implementation of the decisions of the GJEDNJ.13

Strategies and plans of the Albanian government are also part of the future programs, with the clear intention of solving the ownership issues. ${ }^{14}$

Reforms in the area of property rights, after 1990 have been very sensitive. Regarding to an almost non-existing status of private ownership, Albania transferred according to the legal framework, almost most of the former state property. Legal changes have been numerous, (16 separate laws regulating property relations in various fields) operating institutions are numerous (8 institutions) whose activity is regulated by various pieces of legislation, which treat fragmented matter of gaining ownership and registration of property titles. ${ }^{15}$ The high number of institutions and numerous regulatory legislation, create overlapping processes related to property rights.

However during all this strategy we can notice that there are technical infrastructure and human resources that need further improvement of the stuff. International awareness has grown regarding the individual concerns for the Albanian's ownership problems. These problems are cited even in the annual report of European Commission as clear examples of weakness in the human rights protection in Albania and as the misfunction of free-market trade which makes it unable to compete with other European markets which are also three of the main criteria for EU membership.

The government has opposed imposing different policies, but among many obstacles the lack of capacity is one of the major issues in the Albanian justice. ${ }^{16}$

UN WOMEN studies show that in Albania must be done a lot more to respect properly women's property rights. For this, it is recommended to train the central and local staff, who deal with property right issues. This recommendation comes because there has been identified lack of knowledge of the staff that deals with property right issues ${ }^{17} .18$

The Strategy defines as very important the human resources and capacities of the Ministry of Justice and line ministries, who deal with issues of ownership and in the strategy they are considered as an integral part of the administrative system of the executive power. Obstacles to he functioning of public administration, in general, are addressed in the strategy and its action plan ${ }^{19}$.

In the World Bank reports over the years, it has been noted that Albania, due to many factors, has made slow progress in the field of property. Among the main factors are the limited number of human resources, lack of knowledge of the legislation, of institutions and of the legal framework of the field of property. The World Bank has supported institutional development and governance reforms, to help strengthen the capacity of government institutions in the implementation of public goods and the achievement of development outcomes effectively and efficiently.

We are including a part of the World Bank report, on the Status of Land Reform and Real Property markets in Albania. Tirana, 2006.

"Although a source providing precise and recent statistics could not be identified, there is general agreement that about

\footnotetext{
12 Crosscutting Strategy, reform in the area of property rights, the official website of the Ministry of Justice (the first date 01/10/2012)

${ }^{13}$ Crosscutting Strategy, reform in the area of property rights, the official website of the Ministry of Justice (the first date 01/10/2012)

${ }^{14}$ Currently Albania government nr.350 decision dated 29.04.2011, has approved a special plan of action to resolve the problems identified in the Memorandum of the Council of Ministers of the Council of Europe document, which took into account (cited in Strategy Disadvantaged, p 3, (first official faqjen the Ministry of Justice dated 01/10/2012)

15 PhD Lirika Kutrolli, Conference International, Legal Framework in Albania and Integration in Europe, refered the Topic: Legal framework and Integrative reforms concerning ownership and property in Albania, 25-26 november, "Luigj Gurakuqi" University of Shkodra.

${ }_{16}$ World Bank, Governance in the protection of rights over immovable property in Albania. Ongoing challenge, pp. 1-6

17 Inter-Sectorial Strategy Reform in the area of property rights, the official website of the Ministry of Justice (seen on 1.10.2012)

${ }^{18}$ PhD Lirika Kutrolli, Conference International, refered the Topic: " Differentiated Missions in the University Education Institutions" 26-27 october, Europian University of Tirana

${ }^{19}$ Approved by Decision of Council of Ministers, on 12.08.2009
} 
half of all cases in the civil courts involve land and property disputes. ${ }^{20}$ Professionals in the system complain about delays, procedural complexity, the inexperience of judges and court staffs, and limited resources to obtain technical expertise. Judicial orders and judgments are not often registered as the law requires, and there are problems with execution of court orders.

There have been two approaches to address these issues. The Government has undertaken several projects working with judges, lawyers and administrators to improve the operation of the civil courts and upgrade the quality of their substantive decisions. These projects provide training for judges and staff, improved case management and streamlined procedures for bailiffs and related services. These projects do not have a specific focus on land and property cases. The Faculty of Law at Tirana University does not offer comprehensive courses in land or property law.

Some externally-funded projects have worked with local non-governmental organizations to organize mediation services as an alternative to the courts. This activity has led to the adoption of a law allowing parties to submit their disputes to mediator.

However, a formal system of mediation is not in place and recent consultant reports have noted problems in the law. In particular, the law does not authorize judges to transfer cases from the courts to mediation. On an informal level, there is evidence that village elders, municipal officers and other local leaders are called upon frequently to mediate disputes among family members and neighbors. Donors have supported the Albanian Foundation for Conflict Resolution and have assisted other local activities by providing training and the services of social workers, religious leaders and other professionals ${ }^{21}$.

Training of judges, lawyers and staff in the substance of civil property law, land and property transactions and registration is a particular need. At present, the Faculty of Law of the University of Tirana does not offer courses on these subjects, despite the fact that they are fundamental components in the system of civil law. The Magistrates' School also has not madethe land and property issues a routine part of its judicial training, although it has conducted programs, sporadically, on these issues. It does appear necessary to provide the judges with a higher level of support so that they can deal efficiently with the technical aspects of land and property cases in the course of considering the broad spectrum of issues. Thus, assistance in providing the courts with ready access to specialized staff or contracted experts in valuation, survey and map interpretation, soil, water and other environmental measurements would be an important contributio22".

World Banks conclusions come after field observations, and following the submission of the above mentioned piece of report is worth pointing out that there is room for reflection. There must be taken and approved research projects for the introduction of programs rich of legislation themes and property relations, in the law faculties, both in the public and private ones. Currently, in these faculties there are not developed specific subjects required for the development of the country, although in the strategy of the Ministry of Education and Science, among the others, it has been foreseen to realize as follows:

- The development of the economy in general and in particular in regional level, through the establishment of a qualified work,

- The fulfillment of the aspirations of the new generation,

- The development and consolidation of a broad and adequate knowledge serving to the country.

There might be a lot of important factors affecting the implementation of the tasks of the strategy, but what seems to have been ignored somehow is the fact that there should be developed policies about the space to be occupied by specific subjects, which are very necessary for the preparation of professionals, experts and the authorities.

It is exactly:

"The development and consolidation of a broad and adequate knowledge in the service of the country".

There should be developed more policies that lead to the formation and development of "competent people" or people "being comptent" in a particular field.

Examining the cases presented by Albanians to the Human Rights Court, we conclude that Albania ows to many citizens who have won their cases in this Court and the financial bill to be paid by our country is too big and unaffordable. Even in this case, I put into question the ability of officials and lawyers regarding property issues, and again are to be blamed the uncapable lawyers and the unprepared administration as one of the main reasons for presenting this picture of Albania in the international arena. But how should we increase capacities?

Who can help for the preparation and development of the authorities? How should we work in orded we have more

${ }^{20}$ See Norman Singer, (2001), Report of the consultants: Civil Court Matters survey for USAID, July 4-29, 2001, cited in World Bank report; Status of Land Reform and Property market in Albania. Tirana, 2006

21 World Bank, Status of Land Reform and Real Property Market in Albania, pg 18,Tirana 2006

22 World Bank, Status of Land Reform and Real Property Market in Albania, pg 89, Tirana 2006 
competent and skilled lawyers in the field of property? How much attention is paid to research programs for the property subject in the Faculties of Law?

What would best help the current problem solving is the capacity building which would be realised if we look back at the curricula. It would be better if the subject of 'the right of property' was better assessed and given more space, considering it a specific subject as a result of the complexity of the nature of ownership and of the current problems of ownership issues between old and new owners, among institutions and their coordination.

These problems need to be solved and the solution requires capacities, requires qualified people, competent lawyers and skilled experts ${ }^{23}$ and the basis of this qualification, must be sought in the study programs of the Faculty of Law at our universities.

To what extend has the subject of "property rights" been assessed by the faculties of law at our universities, which may name it differently.

Often it is concluded that the administration suffers from a lack of knowledge in this field, and this not only in the administration but at higher levels too, and therefore it is considered as very important that magistrates participate in courses dealing with topics in the field of property and ownership.

To see the importance given to this subject, we searched and researched on the curricula of law faculties in some universities. Almost in most of them, programs do not contain specific and up to date topics. For this reason, there should be given more space in the curricula, in order to transfer the knowledge to students. This way we would influence directly to capacity building, and training at universities lawyers with full knowledge, that will serve to the normalization and solution of property problems, as a fundamental right of every individual.

"The right of Property" is a subject which is taught at the faculties of law, but, in some universities it is developed as a separate subject (although it lacks up to date topics) and in some others its programme is distributed and included in other subjects. It is very important that the curricula should be designed with the appropriate content, in order to respond to the demands of students and current developments in the country. In this case, 'ownership' is a subject which should be developed separately for its role and current importance as a key factor for the development of the country and economy.

Curricula are essential for guiding the knowledge to society, especially to the growing society of students. A very good curricula, will give an opportunity to their formation and capacity building following the development of reforms in the positive direction. The program should completed with specific topics about legislation on land, on the activity of the new structures and institutions, on the activity of the European Court of Human Rights, on the tasks set out in the National Strategy 2013-2020, on the obligations set out in the Action Plan Completing the 12 recommendations of the European Commission Opinion on Albania, where it is stated that there is a lack of knowledge in the field of ownership at all levels of government, central, local and in the judiciary. Should be followed by other universities, in order to convey more knowledge to the students of the Faculty of Law on specific topics in the field of property, to contribute in changing the situation and the place Albania has in the European area and in the European Court of human Rights, where leads with greatest number of complaints made by Albanians for the violation of property rights.

Current reforms are on the right path, and every day is felt more and more the intervention of the state. Policies are clear and orient the respect of the right of property as a basic human right.

\section{Conclusions}

In the programs of the Faculties of Law, there are significant shortcomings in terms of topics and knowledge they are supposed to convey to students, of institutions and current legal changes that ply an important role in property relations as a key factor in the development of the country. Offering increased knowledge to the auditoriums, we will raise a generation of skilled lawyers, by believing that their service will contribute in minimizing the number of cases of violations of individual property rights as a fundamental right.

- The more knowledge the education sector, the academic staff and experts in the field offer, the fewer cases of violations of property rights we will have submitted in the courts of the country, as well as in the European Court of Human Rights, changing this way the image of our country in the international arena, where it is currently stated that Albania is ranked with the greatest percentage in the field of property violations.

${ }^{23}$ World Bank, Report $\mathrm{Nr} 62519-\mathrm{AL}$, Governance in the protection of rights over immovable property in Albania: a constant challenge, the World Bank briefing paper 
- In the auditoriums, the transmission of as much knowledge as possible in the field of intellectual property will lead towards capacity building and training of lawyers who will be able to cope with the new challenges facing our country, especially in the field of property and land ownership legal relations.

\section{Recommendations}

- The subject "The right of property" should be a separate subject.

- In the Faculties of Law, the subject "The property and ownership" or "The Right of Property", should have more space and it should be developed as a separate subject. Resolving property issues is a current challenge for the country. We have all the opportunities and appropriate support from international partners to overcome the identified weaknesses in the area of property rights as a fundamental right, the protection of human rights and the rule of law, and we can achieve that by increasing the capacities, improving the curricula and having "The right of Property " as a separate subject not only in the Faculties of Law, but also in the Faculties of Environmental Ingeneering, etc.

- University Institutions should work more in terms of scientific research, in order to identify gaps in programs related to specific topics in various subjects. Programs should be enriched with updates of recent developments (regarding legal changes and the participation of many institutions in implementing them) which will serve to the knowledge delevery in coherence with current developments.

- Programs rich in land issues and legislation regulating property relations should be developed not only in the Faculties of Law, but also at the Departments of Agronomy, Environment etc.

- The course must have a rich program in order to address issues of land and property \{it should be enriched with specific topics, including legal changes and institutions that deal with these issues\}.

- The right of property presents a great importance, because of the close connection of property-land with the development of the economy. As such, it should be a separate branch for "MASTER", studies as there are "Public Relations" and so on.

\section{References}

Albanian Association of Demographers, Tirane 2012

World Bank, Albania: The new agenda of economic growth, Nov 2010

Official website of the Ministry of Education \{quoted the speech of the Minister of Education and Science, at the conference of 17 October 2011, The Higher Education Reform\}.

Stabilisation and Association Agreement, the short-term priorities (2012-2013)

km.gov.al, 5 October 2012, "Speech of Prime Minister Sali Berisha in the conference of the 20th anniversary of the World Bank.

Archival Fund of the Council of Ministers, Archive of the Department of Public Relations, referring to 2009 and 2011.

Inter-sectorial Strategy, the reform in the area of property rights, the official website of the Ministry of Justice (visited on 10/01/2012)

National Strategy for Development and Integration for 2013-2020 (adopted at the meeting of the Strategic Planning Committee, 20 December 2011).

Decision nr.350, dated 29.04.2011, which has adopted a specific plan of action to resolve the problems identified in the Memorandum of the Council of Ministers of the Council of Europe, taken in consideration (quoted at the Inter-sectorial Strategy, pg. 3,(seen at the official website of the Ministry of Justice, on 10/01/2012).

World Bank, Governance in the protection of rights on immovable property in Albania. An ongoing challenge.

DCM nr.1017, dated 12.08.2009.

See Norman Singer, (2001), Consultant's Report: Survey of the Civil Court Caseload for USAID, July 4-29, 2001 quoted at the World Bank Report "Status of Land Reform and Real Property Markets in Albania", Tirana, 2006.

World Bank, the Status of Land Reform and Property Market in Albania, pg. 18, Tirana 2006.X 